a short communication entitled "Das Problem der Configurationen," by Prof. Reye, of Strassburg. The Editor may be most heartily congratulated on the start he has made: taking everything into account, we have little doubt but that his efforts will be crowned with abundant success.

The most serious difficulty about such an undertaking is that of finance. The American Journal began its career with the Johns Hopkins trustees at its back: we suppose, however, that by this time it walks alone. In the present instance, the mainstay is the enlightened King Oscar the Second. Long may he live! The journal is rightly dedicated to him, the dedication being made appropriately in one of the second-rank languages, which it is cheering for us to see, have sometimes their uses.

M. D.

\section{THE FRENCH MISSION TO CAPE HORN}

7 HE members of the French Magnetic and Meteorological Expedition to Cape Horn have taken up their quarters at Crange Bay, and have already begun work. The accompanying illustration, reproduced from La Nature, after a photograph transmitted to the Paris Academy of Sciences, will give an idea of the aspect of the station occupied by the expedition. On the summit of the hill are the astronumical cabins, beside which are placed a pluviometer and an actinometer. The large house in the middle distance forms the officers' quarters, while the lower building is for the sailors, Along the shore are other structures partly shown in the illustration, a stockade for the tidal register, and an isolated tent for absolute determinations.

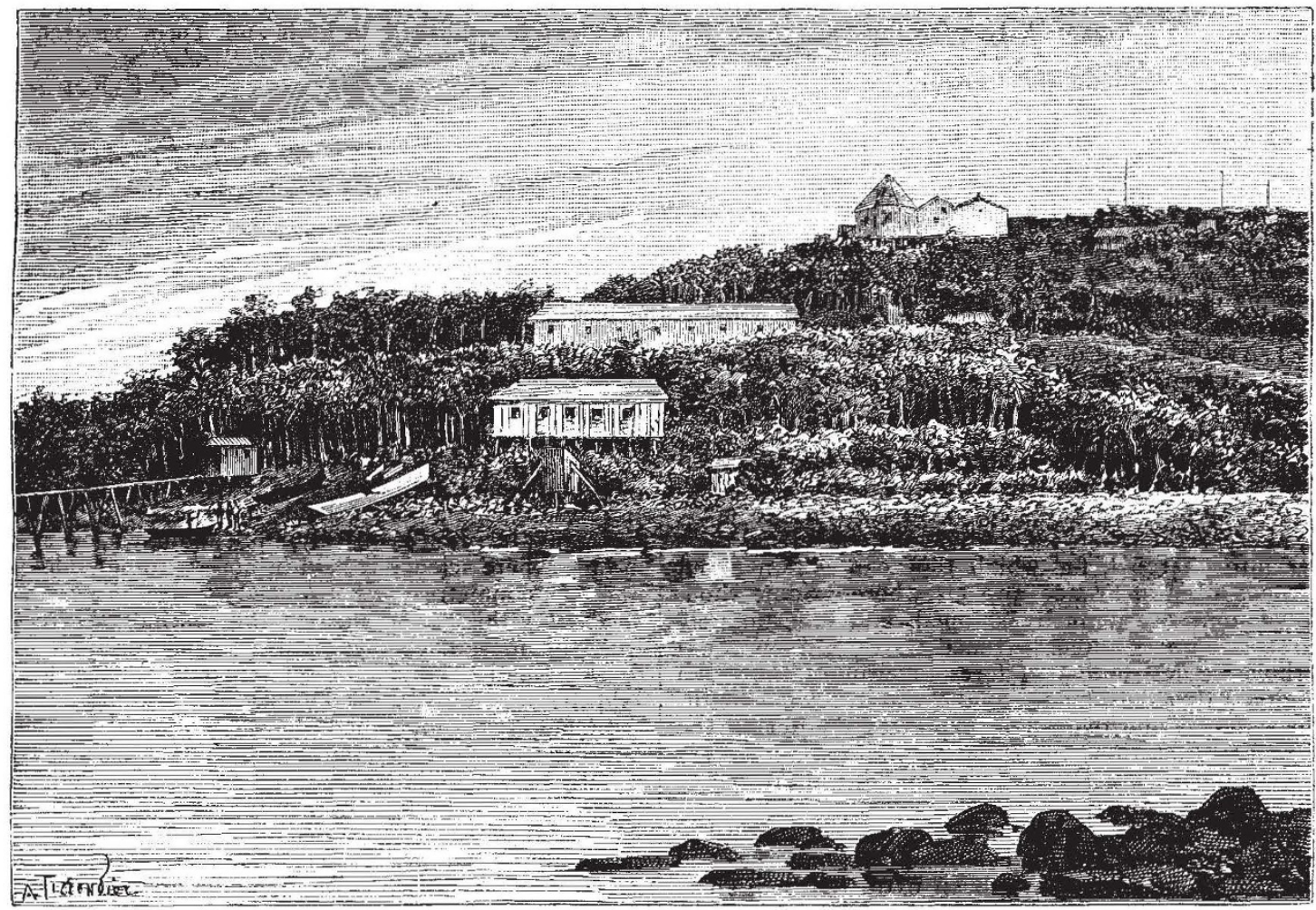

Station of the French Mission to Cape Horn.

The mission arrived at Orange Bay, Terra del Fuego, on September 6 last. Tł.ey found the country marshy, and were compelled to select a wooded spot in order to obtain firm ground. No time was lost in erecting inclosings and installing the various instruments; and on September 26, the meteorological and magnetical observations were begun. Since the arrival of the party the temperature at Orange Bay has been very mild; the thermometer has never been below $0^{\circ} \mathrm{C}$., and several times it has been as high as $16^{\circ}$. The air is very moist, and there has been plentiful rain almost every day, though not lasting long. Squalls have been rare. The magnetic observations will be made partly by instruments which will be read directly, - absolute determinations of declination, inclination, horizontal force, \&c., and partly by means of regulating apparatus, which, so far, have worked very satisfactorily, and bave given indications agreeing with those obtained from direct-reading mag- netometers. The other duties of the expedition consist in astronomical and meteorological observations.

The expedition has been well received by the natives, one of whom speaks and reads English fluently. Indeed, twenty miles off, in Beagle Channel, is an English mis. sion station, which is reported to be very prosperous. On the whole, the French expedition has been very successful ; it may be regarded as one of the International Polar Observing Stations.

\section{HEATING BY ACETATE OF SODA}

M A. ANCELIN, Civil Engineer, describes in $L a$ N1. Nature a method he has devised of heating for do. mestic purposes, travelling, \&c. , by means of acetate of soda. His object has been to deyise a method that will possess all the advantages of heating by means of hot water, without any of its inconveniences. For this purpose he sought 